\title{
Thermal stability of materials of vegetable origin
}

\author{
Tetiana Korinchevska, Viacheslav Mykhailyk \\ Department of Heat and Mass Transfer in Heat Technologies, Institute of Engineering Thermophysics of \\ NAS of Ukraine, UKRAINE, Kyiv, 2 Academician Bulakhovsky Str., E-mail: tvkorin@gmail.com
}

\begin{abstract}
The behavior of vegetable samples at programmed heating up to $270{ }^{\circ} \mathrm{C}$ was studied by the method of thermal analysis. The stage of water removal is considered. Moisture, average rate and conditional thermal effect of water removal are calculated. The temperature of the beginning of thermal destruction of materials is determined.
\end{abstract}

Keywords - thermal analysis, thermal stability, destruction, vegetables, dehydration.

\section{Introduction}

Vegetables are an important component in the production of various foods. Since they are high-moisture products, they can quickly lose their natural value during storage. Preserving by drying is one of the reliable and effective ways to protect vegetables from spoilage. Qualitative characteristics of dried products depend on the choice of dehydration mode. The temperature of the material during drying is one of the main mode parameters which provides high quality of the product, nutritional value and preservation of the whole complex of biologically active substances. Therefore, it is important to know the temperature after which the process of thermal destruction begins. This temperature determines the thermal stability of materials.

\section{Materials and methods}

Samples of vegetable products (Table 1) were selected as the most available and widely used in the Ukrainian market. The thermal stability of the samples was determined by the method of thermal analysis on the derivatograph "Q-1000", modernized in the IET of NAS of Ukraine.

For research, the samples were crushed to ensure the homogeneity of the structure. The mass of the samples was 187.0 - $202.4 \mathrm{mg}$. Prepared samples were placed in a conical platinum crucible from the device kit. $\mathrm{Al}_{2} \mathrm{O}_{3}$ was used as an inert substance. The obtained samples were subjected to programmed heating at a rate of $3.6 \mathrm{~K} / \mathrm{min}$ in the range of $20-270{ }^{\circ} \mathrm{C}$. The collection and processing of information from the channels of measurement was performed using the applied computer program "Derivatograph". The temperature deviation did not exceed $\pm 0.5 \mathrm{~K}$. The change in temperature and mass of the sample, the rate of change in mass, and the thermal effect were registered during the experiment.

\section{Results}

Structural-mechanical and physico-chemical changes in the material occur during heating. Since all the studied materials are high-moisture products, their heating is accompanied by the removal of water. The endothermic effect is registered in the range from ambient temperature to $164-210{ }^{\circ} \mathrm{C}$ depending on the type of product (Table 1). The determined moisture of the samples varies from $61.51 \%$ for garlic to $92.45 \%$ for white cabbage.

The rate of dehydration of the studied vegetables increases with increasing temperature and reaches a maximum at $117-128{ }^{\circ} \mathrm{C}$ and further decreases to almos to zero. The average rate of dehydration of the samples is defined in the range from 1.36 to $2.00 \% / \mathrm{min}$. Moreover, for potatoes and garlic, the rate is the lowest and is 1.36 and $1.42 \% / \mathrm{min}$ in accordance. White cabbage, onion, roots of parsley and celery have the maximum water removal rate $(1.97$ - 
$2.00 \% / \mathrm{min}$ ). It can be noted that the average rate of dehydration directly depends on the initial moisture of the product (Table 1).

Table 1

The results of processing the obtained data of thermal analysis of vegetables

\begin{tabular}{|l|l|c|c|c|c|c|c|}
\hline \multirow{2}{*}{ № } & Material & $\begin{array}{c}\text { Temperature } \\
\text { interval, } \\
{ }^{\circ} \mathrm{C}\end{array}$ & $\begin{array}{c}\text { Maximum } \\
\text { of rate, } \\
{ }^{\circ} \mathrm{C}\end{array}$ & $\begin{array}{c}\text { Mois- } \\
\text { ture, } \%\end{array}$ & $\begin{array}{c}\text { Average } \\
\text { rate, } \\
\% / \mathrm{min}\end{array}$ & $\begin{array}{c}\text { Condi- } \\
\text { tional } \\
\text { thermal } \\
\text { effect, } \\
\mathrm{mV} \cdot \mathrm{s} / \mathrm{mg}\end{array}$ & $\begin{array}{c}\text { The } \\
\text { beginning } \\
\text { of thermal } \\
\text { destruction, } \\
{ }^{\circ} \mathrm{C}\end{array}$ \\
\hline 1 & Potato & $24-210$ & 122 & 72,29 & 1,36 & 91,20 & 210 \\
\hline 2 & Carrots & $22-179$ & 117 & 86,84 & 1,93 & 95,13 & 179 \\
\hline 3 & Beetroot & $25-179$ & 121 & 82,44 & 1,83 & 103,30 & 179 \\
\hline 4 & Pumpkin & $22-184$ & 125 & 84,11 & 1,85 & 93,37 & 184 \\
\hline 5 & $\begin{array}{l}\text { White } \\
\text { cabbage }\end{array}$ & $24-186$ & 123 & 92,45 & 2,00 & 97,42 & 186 \\
\hline 6 & $\begin{array}{l}\text { Parsley } \\
\text { root }\end{array}$ & $21-164$ & 121 & 82,79 & 1,97 & 97,77 & 164 \\
\hline 7 & $\begin{array}{l}\text { Celery } \\
\text { root }\end{array}$ & $23-181$ & 128 & 90,14 & 1,98 & 96,13 & 181 \\
\hline 8 & Onion & $22-179$ & 123 & 88,93 & 1,98 & 99,37 & 179 \\
\hline 9 & Garlic & $23-172$ & 126 & 61,51 & 1,42 & 97,83 & 172 \\
\hline
\end{tabular}

Gradual mass loss is registered after complete removal of water, which indicates the thermal destruction of certain components of the material. The change in mass is accompanied by a noticeable release of heat in the studied temperature interval for all samples except potatoes and cabbage. However, this study does not allow to establish which component decomposes. The temperature of the beginning of thermal destruction is in the range from $164{ }^{\circ} \mathrm{C}$ for parsley root to $210{ }^{\circ} \mathrm{C}$ for potatoes.

The conditional thermal effect was determined to compare the heat consumption for water removal. The results (Table 1) show that the most heat is expended during dehydration of beetroot, and the least - potatoes. This may be due to the different ratio of free and bound water in the samples [1].

\section{Conclusion}

The results of thermal analysis of samples of vegetable raw materials allowed to determine their moisture, thermal stability, average rate of dehydration and to estimate heat consumption for dehydration using the conditional thermal effect.

\section{References}

[1] Mykhailyk, V. A., Dmitrenko, N. V., \& Mykhailyk T. A. (2007) Vliyanie termicheskogo vozdeystviya na sostoyanie vodyi v rastitelnyih tkanyah. Promyishlennaya teplotehnika. 29(7), 212-217. 